\title{
PRACTICAL IMPLICATION OF TAP WATER CONSUMTPION STRUCTURE IN RURAL HOUSEHOLDS
}

\author{
Tomasz Bergel ${ }^{1}$ \\ Department of Sanitary Engineering and Water Management, University of Agriculture in Cracow, Mickie- \\ wicza 24/28, 30-059 Kraków, Poland, e-mail: t.bergel@ur.krakow.pl
}

Received: 2016.10.15

Accepted: 2016.11.16

Published: 2017.01.01

\begin{abstract}
The aim of the study was to determine the structure of tap water consumption in rural households. The structure was analyzed based on direct measurements of water consumption carried out in the years 2011-2014 in 70 households in Rybna (Czernichów commune, Małopolska region). Thanks to two metering points (water supply connection and water supply point outside a residential building), it was possible to determine water consumption for the household and other purposes. The collected data indicated significant discrepancies between actual water consumption and those recommended in various guidelines. The analysis of water consumption structure showed that these discrepancies were also found for the amount of domestic sewage discharged from the rural households. This fact has significant practical implications, as the calculated metrics of unit water consumption are used during design and technical renovation of individual elements of water supply systems and for billing the inhabitants for water consumption in the households without a water meter (lump sum). The study also demonstrated inadequacy of the rule assuming that sewage amount is equal to the amount of water consumed in rural households, which is commonly used in design of sewerage networks and for calculating charges for sewage discharge.
\end{abstract}

Keywords: rural household, water consumption, water consumption structure

\section{INTRODUCTION}

Dimensioning of water supply and sewerage systems is based on correct determination of water demand that is a difficult and important task. Observations of existing water supply and sewerage systems indicate that many of them were incorrectly dimensioned at the design stage. This causes suboptimal use of funds allocated for investment projects and significant increase in operating costs compared to the design assumptions. Another result is that the assumed technological effects are not achieved in some of the solutions. Researchers working in this field blame mainly the use of outdated guidelines that do not reflect actual conditions. Analyses of water consumption conducted by numerous authors showed considerable discrepancies between the actual water consumption and that assumed for design purpos- es. Most rural water supply systems do not work at their full design capacity even after many years of operation. These discrepancies reduce also the reliability of water supply [Pawęska et al. 2013].

Correct determination of water demand is also important for planning of development and modernization of water supply and sewerage systems and calculating charges for water consumption and sewage collection. Water companies sell less and less water but they invest more and more in improving water quality and this requires large amounts of money [Bergel 2005]. Incorrect estimation of water demand and assuming higher than real water consumption may result in lower than expected water charges and there might be not enough funds to cover actual costs of the water companies [Roman et al. 1996].

Therefore, an analysis of water consumption structure may be very helpful in correct de- 
termination of unit water consumption. In rural households, water is used for two main purposes: domestic and other (livestock breeding, maintenance of livestock buildings, watering crops and home gardens, diluting plant protection products, washing cars and agricultural machinery and household-specific purposes such as filling a swimming-pool in the summer). The water used for meeting everyday needs is consumed and discharged into a sewerage system as sewage but the water used for meeting other needs is called nonreturnable water as it is often not discharged via the sewerage system. In recent years, a noticeable increase in water consumption for other purposes has been observed in rural communities. This is due to such factors as an increase in the number of vehicles and their frequent washing, greater attention of the inhabitants to their premises, common use of plant protection products and watering crops and greeneries. Therefore, the structure of water consumption is the main parameter affecting the amount and type of sewage discharged from the households. However, a rule of thumb assuming that the amount of discharged sewage is equal to the amount of consumed water, still followed by many designers, has the following practical implications [Bergel, 2005]:

- overestimating the costs of construction and operation of sewerage systems,

- worsening the effects of sewage treatment,

- oversizing of the sewerage network and wastewater treatment plants,

- overestimating the fees paid by sewerage system users for sewage disposal.

To avoid such situations, farm owners often install additional water meters that measure the amount of non-returnable water consumption. Installation of an additional water meter allows them to reduce costs, as the fee is charged only for water consumption and not for sewage discharge. Technical conditions for the installation of an additional water meter may be issued to the owners of single-family houses and agricultural or horticultural farms [Ustawa...2001].

Data from such measurements are also extremely valuable for water companies, designers and researchers in the field of water consumption. They provide information on the metrics of water consumption and sewage discharge that are used at all stages of technical operation of water supply and sewerage systems, i.e. during design, construction and operation.
The aim of this study was to provide an analysis of water consumption structure in rural households in terms of practical applicability of these results.

\section{MATERIALS AND METHODS}

The research was based on direct measurements of water consumption in selected rural households that served as a reflection of Polish countryside. They included typical agricultural farms inhabited by people living off their land and also households not involved in any agricultural production and not differing in anything from the houses situated in cities apart from their village location.

The study was conducted from 1 January, 2011 to 31 December, 2014 in 70 households in Rybna (Czernichów commune, Małopolska region). Total water consumption in the household and water consumption for such purposes as livestock breeding, watering crops and greeneries, washing of cars and agricultural vehicles and machinery, cleaning the premises, diluting chemical plant protection products, and other purposes, was determined based on quarterly readings of the main and the additional water meter in the analyzed households. Water for other purposes was usually taken from faucets located in utility rooms or outside. Apart from the readings of the main and additional water meter, the study also recorded the current number of inhabitants.

It was also possible to calculate water consumption for household purposes that constituted the difference between the readings of the main and additional water meter. Taking into account the number of inhabitants, unit water consumption for these purposes and consequently unit amount of household sewage were worked out.

Total water consumption was calculated per conversion inhabitant $\left(\mathrm{dm}^{3} \cdot \mathrm{CI}^{-1} \cdot \mathrm{d}^{-1}\right)$, structure of water consumption per household $\left(\mathrm{dm}^{3} \cdot \mathrm{H}^{-1} \cdot \mathrm{d}^{-1}\right)$ and water consumption for the household purposes per inhabitant $\left(\mathrm{dm}^{3} \cdot \mathrm{I}^{-1} \cdot \mathrm{d}^{-1}\right)$.

\section{RESULTS AND DISCUSSION}

\section{Water consumption per conversion inhabitant}

Direct measurements of water consumption enabled determination of total daily water consumption in a household. Then, taking into ac- 
count total water consumption and the number of inhabitants, water consumption per conversion inhabitant (CI) was calculated.

Mean, minimum, and maximum water consumption per capita for the study period in the investigated villages are presented in Table 1. Mean total water consumption per conversion inhabitant in Rybna was $95.0 \mathrm{dm}^{3} \cdot \mathrm{Cl}^{-1} \cdot \mathrm{d}^{-1}$.

This was less than the value reported by Pawełek and Kaczor [2008], which amounted to $153.4 \mathrm{dm}^{3} \cdot \mathrm{CI}^{-1} \cdot \mathrm{d}^{-1}$ but it was consistent with the results provided by Bugajski and Kaczor [2007], who claimed mean total water consumption to

Table 1. Total water consumption per conversion inhabitant

\begin{tabular}{|c|c|c|c|c|}
\hline \multirow{2}{*}{ Year } & \multirow{2}{*}{$\begin{array}{l}\text { Measur- } \\
\text { ing period }\end{array}$} & \multicolumn{3}{|c|}{ Water consumption $\left[\mathrm{dm}^{3} \cdot \mathrm{Cl}^{1} \cdot \mathrm{d}^{-1}\right]$} \\
\hline & & mean & maximum & minimum \\
\hline \multirow{5}{*}{2011} & Q1 & 90.0 & 233.3 & 15.6 \\
\hline & Q2 & 94.4 & 208.8 & 25.6 \\
\hline & Q3 & 152.6 & 326.1 & 34.4 \\
\hline & Q4 & 46.4 & 168.5 & 5.4 \\
\hline & mean & 95.8 & 234.2 & 20.3 \\
\hline \multirow{5}{*}{2012} & Q1 & 87.5 & 205.6 & 11.1 \\
\hline & Q2 & 86.5 & 203.3 & 23.8 \\
\hline & Q3 & 162.3 & 364.1 & 43.5 \\
\hline & Q4 & 43.3 & 169.0 & 10.9 \\
\hline & mean & 94.9 & 235.5 & 22.3 \\
\hline \multirow{5}{*}{2013} & Q1 & 96.1 & 300.0 & 11.1 \\
\hline & Q2 & 89.5 & 230.8 & 26.4 \\
\hline & Q3 & 103.4 & 282.6 & 26.1 \\
\hline & Q4 & 110.0 & 290.8 & 10.9 \\
\hline & mean & 99.7 & 276.1 & 18.6 \\
\hline \multirow{5}{*}{2014} & Q1 & 84.6 & 277.8 & 15.9 \\
\hline & Q2 & 80.1 & 230.8 & 8.8 \\
\hline & Q3 & 98.7 & 271.7 & 32.6 \\
\hline & Q4 & 94.3 & 271.7 & 30.4 \\
\hline & mean & 89.4 & 263.0 & 21.9 \\
\hline
\end{tabular}

range between 67.0 and $135.0 \mathrm{dm}^{3} \cdot \mathrm{CI}^{-1} \cdot \mathrm{d}^{-1}$. Mean water consumption per conversion inhabitant in Rybna was below average in 2012 and 2014 but above this value in the other years of the study.

Typical intervals of total water consumption per conversion inhabitant were presented in a form of histograms (Fig. 1). Analysis of water consumption per conversion inhabitant revealed that the most common interval was the one between 50 and $100 \mathrm{dm}^{3} \cdot \mathrm{CI}^{-1} \cdot \mathrm{d}^{-1}$. It was reported for $44 \%$ of the measurements. Water consumption ranging from 0 to 50 and from 100 to $150 \mathrm{dm}^{3} \cdot \mathrm{CI}^{-1} \cdot \mathrm{d}^{-1}$ was much less frequent and was reported for $20 \%$ and $21 \%$ of all measurements, respectively. Water consumption exceeding $150 \mathrm{dm}^{3} \cdot \mathrm{CI}^{-1} \cdot \mathrm{d}^{-1}$ was recorded in only $15 \%$ of all cases.

Descriptive statistics for water consumption per conversion inhabitant are presented in Table 2. They indicate high variability of this metrics in the years 2011-2014. This is confirmed by the value of standard deviation that was $58.0 \mathrm{dm}^{3} \cdot \mathrm{CI}^{-1} \cdot \mathrm{d}^{-1}$, and differed by $61 \%$ from the

Table 2. Descriptive statistics of water consumption per conversion inhabitant

\begin{tabular}{|l|c|c|}
\hline \multicolumn{1}{|c|}{ Parameter } & Unit & Value \\
\hline $\begin{array}{l}\text { Number of } \\
\text { observations }\end{array}$ & {$[\mathrm{pc}]$} & 1120 \\
\hline Mean & {$\left[\mathrm{dm}^{3} \cdot \mathrm{Cl}^{-1} \cdot \mathrm{d}^{-1}\right]$} & 95.0 \\
\hline Median & {$\left[\mathrm{dm}^{3} \cdot \mathrm{Cl}^{-1} \cdot \mathrm{d}^{-1}\right]$} & 82.2 \\
\hline Modal value & {$\left[\mathrm{dm}^{3} \cdot \mathrm{Cl}^{-1} \cdot \mathrm{d}^{-1 /}\right.$} & $43.5 / 13 \mathrm{pcs}$. \\
\hline Minimum & {$\left[\mathrm{pc}^{3} \cdot \mathrm{Cl}^{-1} \cdot \mathrm{d}^{-1}\right]$} & 5.4 \\
\hline Maximum & {$\left[\mathrm{dm}^{3} \cdot \mathrm{Cl}^{-1} \cdot \mathrm{d}^{-1}\right]$} & 364.1 \\
\hline Standard deviation & {$\left[\mathrm{dm}^{3} \cdot \mathrm{Cl}^{-1} \cdot \mathrm{d}^{-1}\right]$} & 58.0 \\
\hline Skewness & {$[-]$} & 1.4 \\
\hline Kurtosis & {$[-]$} & 2.4 \\
\hline
\end{tabular}

Rybna

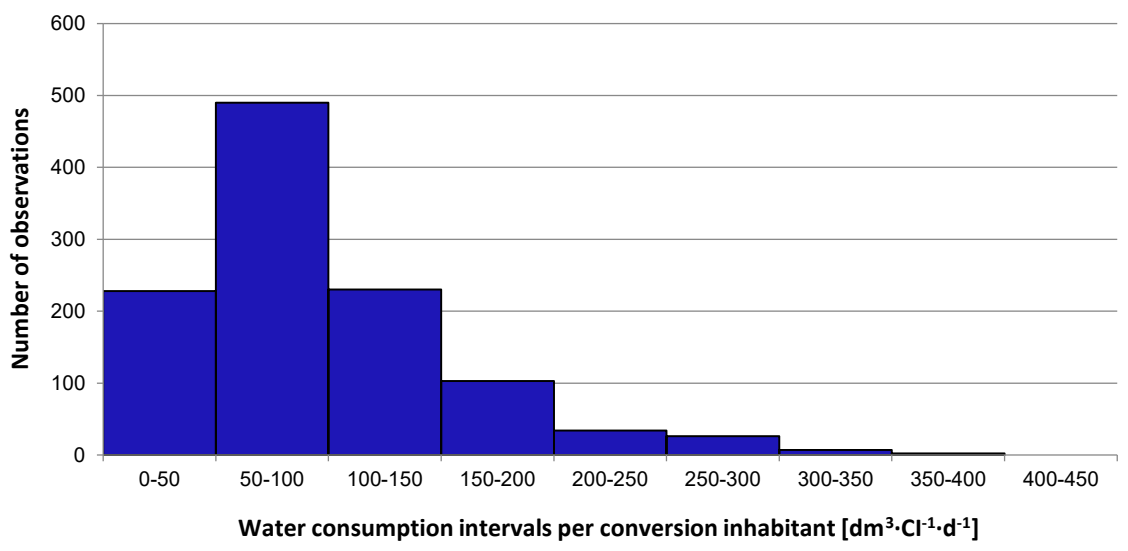

Figure 1. Histogram of total water consumption per conversion inhabitant 
average. The most common value of water consumption per conversion inhabitant in Rybna was $43.5 \mathrm{dm}^{3} \cdot \mathrm{Cl}^{-1} \cdot \mathrm{d}^{-1}$, and the coefficient of skewness indicated that majority of the results were below the average.

\section{Structure of water consumption}

Double metering of water consumption, i.e. at the main water meter on water supply connection and the additional water meter at water supply points outside the residential buildings enabled determination of water consumption for household and other purposes in the investigated households. This solution offered also a possibility of distinguishing from total consumption the amount of water that after use is converted into domestic sewage and discharged into the sewerage system.

Table 3 contains mean values of water consumption for household and other purposes for individual quarters. Different patterns of water consumption per quarter may be observed that are mainly due to different seasons of the year. Mean daily water consumption for household (H) purposes varied, depending on the quarter, from 148.8 to $559.0 \mathrm{dm}^{3} \cdot \mathrm{H}^{-1} \cdot \mathrm{d}^{-1}$. Water consumption for other purposes ranged from 23.3 to 94.5

Table 3. Structure of water consumption in Rybna

\begin{tabular}{|c|c|c|c|}
\hline \multirow[b]{2}{*}{ Year } & \multirow{2}{*}{$\begin{array}{l}\text { Measuring } \\
\text { period }\end{array}$} & \multicolumn{2}{|c|}{ Water consumption $\left[\mathrm{dm}^{3} \cdot \mathrm{H}^{-1} \cdot \mathrm{d}^{-1}\right]$} \\
\hline & & $\begin{array}{c}\text { Household } \\
\text { purposes }\end{array}$ & Other purposes \\
\hline \multirow{5}{*}{2011} & Q1 & 326.5 & 45.6 \\
\hline & Q2 & 350.5 & 47.2 \\
\hline & Q3 & 534.3 & 91.6 \\
\hline & Q4 & 155.7 & 26.8 \\
\hline & mean & 341.8 & 52.8 \\
\hline \multirow{5}{*}{2012} & Q1 & 334.1 & 28.7 \\
\hline & Q2 & 325.6 & 38.6 \\
\hline & Q3 & 559.0 & 94.5 \\
\hline & Q4 & 148.8 & 23.3 \\
\hline & mean & 341.9 & 46.3 \\
\hline \multirow{5}{*}{2013} & Q1 & 356.7 & 39.7 \\
\hline & Q2 & 325.2 & 39.3 \\
\hline & Q3 & 348.3 & 68.5 \\
\hline & Q4 & 389.7 & 64.7 \\
\hline & mean & 355.0 & 53.1 \\
\hline \multirow{5}{*}{2014} & Q1 & 322.7 & 38.6 \\
\hline & Q2 & 296.9 & 35.1 \\
\hline & Q3 & 338.0 & 59.8 \\
\hline & Q4 & 347.3 & 44.4 \\
\hline & mean & 326.2 & 44.5 \\
\hline
\end{tabular}

$\mathrm{dm}^{3} \cdot \mathrm{H}^{-1} \cdot \mathrm{d}^{-1}$. It was the highest in the third quarter, which may be due to such factors as watering crops and greeneries, more often washing of cars, filling swimming pools, greater attention to the premises, and dilution of chemical plant protection products. It was the lowest in the first and second quarter, when water was mainly used for household purposes and livestock breeding. In these periods, water consumption for other purposes was significantly reduced or even disappeared completely in some households.

An analysis of percentage share of daily water consumption for individual purposes demonstrated that on average $85.3 \%$ (83.6-92.1\%) of water was used for household purposes and $14.7 \%$ (7.9-16.4\%) was used for other purposes.

A comparison of these results with those published by other authors showed that mean water consumption for household purposes in Rybna was by $7.3 \%$ higher than the value of $78 \%$ reported by Pawełek and Bergel [2003]. Water consumption for other purposes was also by $7.3 \%$ lower than that provided by these authors (22\%). Exemplary structure of water consumption in the analyzed households is presented in Figure 2.

\section{Unit water consumption for household purposes/domestic sewage discharge}

As mentioned before, the amount of water used for household purposes is related to the amount of generated sewage that is then discharged via the sewerage system to a wastewater treatment plant. According to the calculations provided in the previous section, mean daily water consumption for these purposes in the analyzed period was $341.2 \mathrm{dm}^{3} \cdot \mathrm{H}^{-1} \cdot \mathrm{d}^{-1}$.

The data on water consumption for household purposes and the number of inhabitants were used to calculate unit water consumption per inhabitant (I) that might be the basis for determination of unit discharge of domestic sewage from rural households. Table 4 presents mean values of unit water consumption (sewage discharge) in individual quarters for the years 2011-2014. They ranged within a wide interval of 36.3-134.4 $\mathrm{dm}^{3} \cdot \mathrm{I}^{-1} \cdot \mathrm{d}^{-1}$, with mean values for individual years between 77.1 and $84.4 \mathrm{dm}^{3} \cdot \mathrm{I}^{-1} \cdot \mathrm{d}^{-1}$ (on average $\left.81.0 \mathrm{dm}^{3} \cdot \mathrm{I}^{-1} \cdot \mathrm{d}^{-1}\right)$.

Mean amount of water used for household purposes in Rybna was by $13.9 \mathrm{dm}^{3} \cdot \mathrm{I}^{-1} \cdot \mathrm{d}^{-1}$ higher than the value of $67.1 \mathrm{dm}^{3} \cdot \mathrm{I}^{-1} \cdot \mathrm{d}^{-1}$ reported by Kaczor [2006]. This amount was significantly different from that of $150 \mathrm{dm}^{3} \cdot \mathrm{I}^{-1} \cdot \mathrm{d}^{-1}$ set 


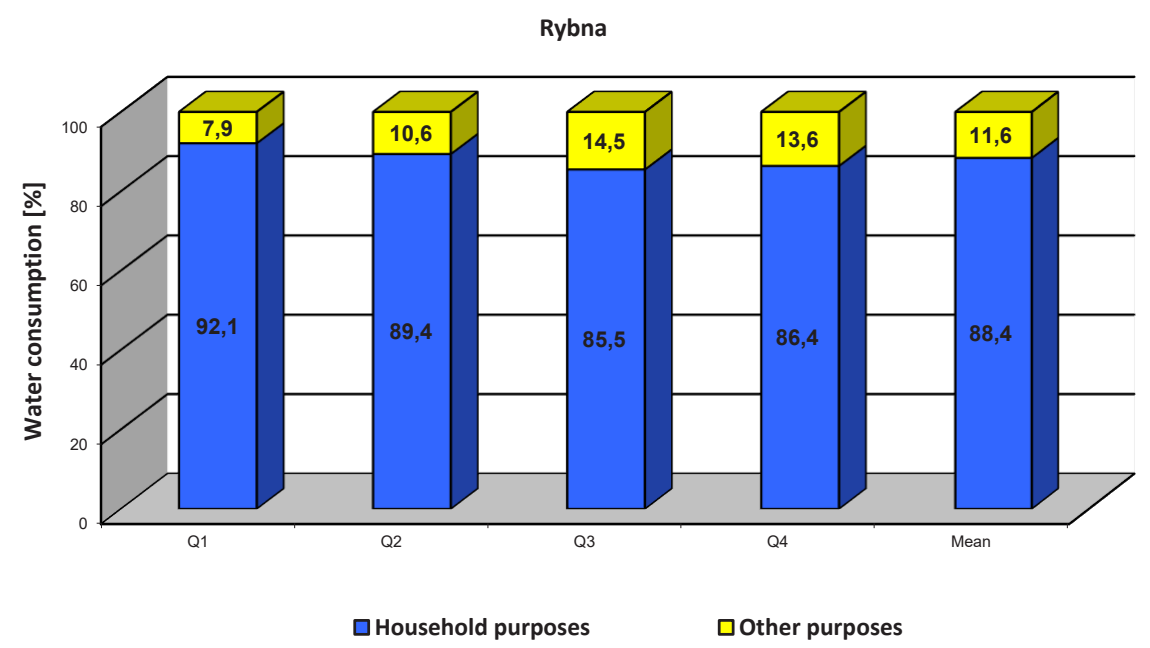

Figure 2. Structure of total water consumption in the analyzed households in 2012

Table 4. Mean daily water consumption for household purposes (domestic sewage discharge) in the years 2011-2014

\begin{tabular}{|c|c|c|}
\hline Year & Measuring period & $\begin{array}{l}\text { Water consumption } \\
{\left[\left.\mathrm{dm}^{3} \cdot\right|^{-1} \cdot \mathrm{d}^{-1}\right]}\end{array}$ \\
\hline \multirow{5}{*}{2011} & Q1 & 77.8 \\
\hline & Q2 & 82.4 \\
\hline & Q3 & 126.6 \\
\hline & Q4 & 37.8 \\
\hline & mean & 81.2 \\
\hline \multirow{5}{*}{2012} & Q1 & 78.5 \\
\hline & Q2 & 75.5 \\
\hline & Q3 & 134.4 \\
\hline & Q4 & 36.3 \\
\hline & mean & 81.2 \\
\hline \multirow{5}{*}{2013} & Q1 & 84.5 \\
\hline & Q2 & 77.3 \\
\hline & Q3 & 83.6 \\
\hline & Q4 & 92.1 \\
\hline & mean & 84.4 \\
\hline \multirow{5}{*}{2014} & Q1 & 74.5 \\
\hline & Q2 & 70.3 \\
\hline & Q3 & 81.9 \\
\hline & Q4 & 81.8 \\
\hline & mean & 77.1 \\
\hline
\end{tabular}

out in the design guidelines or the values provided by Jóźwiakowski [2012] that ranged from 140 to $220 \mathrm{dm}^{3} \cdot \mathrm{I}^{-1} \cdot \mathrm{d}^{-1}$.

The most common values of unit water consumption for household purposes (sewage discharge) were presented on a histogram in Figure 3. Water consumption for household purposes that was the benchmark for determination of domestic sewage amount followed the pattern of water consumption per capita as the most com- mon interval was $50-100 \mathrm{dm}^{3} \cdot \mathrm{I}^{-1} \cdot \mathrm{d}^{-1}$, and the second most common interval was $0-50 \mathrm{dm}^{3} \cdot \mathrm{I}^{-1} \cdot \mathrm{d}^{-1}$. This was due to not including non-returnable water consumption in total water consumption that caused a shift in the consumption from higher to lower intervals.

Table 5 contains descriptive statistics for water consumption (sewage discharge) per capita presented in the histograms. Standard deviation was $46.4 \mathrm{dm}^{3} \cdot \mathrm{I}^{-1} \cdot \mathrm{d}^{-1}$ and differed by $57.3 \%$ from the mean value, thus indicating significant variability of water consumption for household purposes and consequently sewage discharge. The highest unit sewage discharge was 323.4 $\mathrm{dm}^{3} \cdot \mathrm{I}^{-1} \cdot \mathrm{d}^{-1}$, and the lowest was $4.4 \mathrm{dm}^{3} \cdot \mathrm{I}^{-1} \cdot \mathrm{d}^{-1}$. Skewness coefficient indicated that most of the results were below the mean value.

The volume of domestic sewage discharged from rural households is currently determined based on water consumption and does not allow for its structure. Our analysis of mean water consumption per capita and mean water consumption for household purposes (sewage discharge) demonstrated that the actual volume of domestic sewage discharged from the rural households was lower than total water consumption. Therefore, following the assumption that the volume of domestic sewage discharged from the households is equal to the volume of consumed water is unjustified.

Investigation of water consumption structure showed that actual unit discharge of domestic sewage from the rural households in Rybna amounted to $85.6 \%$ of water consumption per capita. This value was lower than reported by some authors. For example, Ćwiertnia [2004], claimed that the 


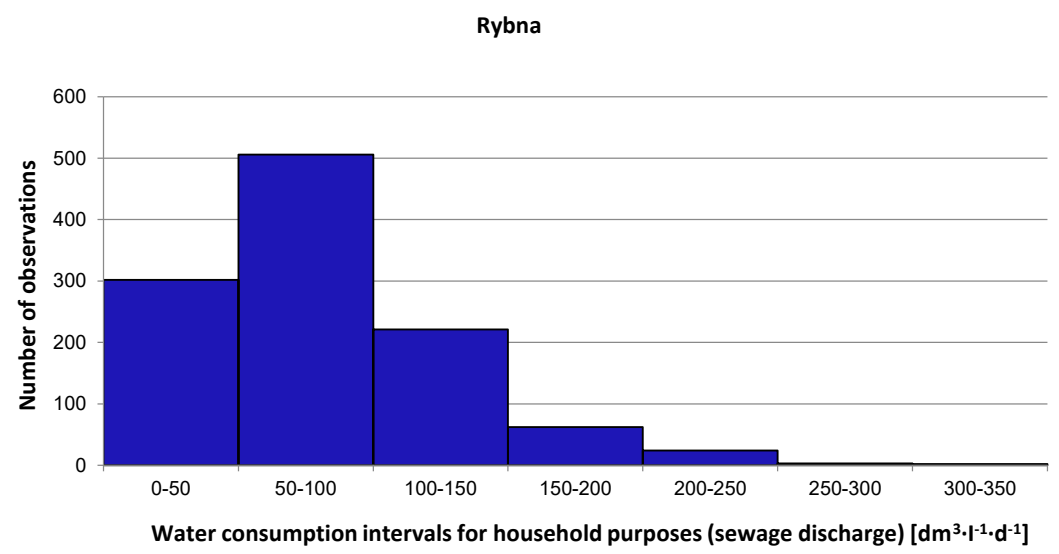

Figure 3. Histogram of water consumption for household purposes (domestic sewage discharge) in Rybna in the years 2011-2014

Table 5. Descriptive statistics of water consumption for household purposes (domestic sewage discharge) in the investigated households

\begin{tabular}{|c|c|c|}
\hline $\begin{array}{c}\text { Parameter } \\
\begin{array}{c}\text { Number of } \\
\text { observations }\end{array}\end{array}$ & Unit & Value \\
\hline Mean & {$[\mathrm{pc}]$} & 1120 \\
\hline Median & {$\left[\left.\mathrm{dm}^{3} \cdot\right|^{-1} \cdot \mathrm{d}^{-1}\right]$} & 81.0 \\
\hline Modal value & {$\left[\mathrm{dm}^{-1} \cdot \mathrm{d}^{-1}\right]$} & 74.6 \\
\hline Minimum & $\left.\mathrm{d}^{-1} \mathrm{pc}.\right]$ & $32.6 / 16 \mathrm{pcs}$. \\
\hline Maximum & {$\left[\left.\mathrm{dm}^{3} \cdot\right|^{-1} \cdot \mathrm{d}^{-1}\right]$} & 4.4 \\
\hline Standard deviation & {$\left[\left.\mathrm{dm}^{3} \cdot\right|^{-1} \cdot \mathrm{I}^{-1} \cdot \mathrm{d}^{-1}\right]$} & 323.4 \\
\hline Skewness & {$[-]$} & 46.4 \\
\hline Kurtosis & {$[-]$} & 1.1 \\
\hline
\end{tabular}

volume of discharged sewage was ca. $93 \%$ of the volume of consumed water, and according to Heidrich [1998] it was about 90-95\%. Values similar to those reported in this study were obtained by Bergel and Kaczor [2007], who argued that they ranged from $76 \%$ to $86 \%$.

\section{CONCLUSIONS}

The study on water consumption and on the relationships between water consumption and sewage discharge in the rural households conducted in the years 2011-2014 allowed for drawing the following conclusions:

1. Mean total water consumption in a household per capita was only $95.0 \mathrm{dm}^{3} \cdot \mathrm{Cl}^{-1} \cdot \mathrm{d}^{-1}$.

2 . The structure of water consumption revealed that $85.3 \%$ of water was used for household purposes and $14.7 \%$ was allocated for other purposes.
3. The volume of sewage discharged into the sewerage system was not equal to the total volume of water consumed in a household and depended on non-returnable water use for other purposes.

4. Mean value of water consumption for household purposes that should be the basis for determining the volume of sewage discharged from rural households was $81.0 \mathrm{dm}^{3} \cdot \mathrm{I}^{-1} \cdot \mathrm{d}^{-1}$.

5. Mean unit sewage discharge from the investigated households was much lower than the values provided in the guidelines. It amounted to only $54 \%$ of $150 \mathrm{dm}^{3} \cdot \mathrm{I}^{-1} \cdot \mathrm{d}^{-1}$, i.e. the value most often used at the design stage.

6. Analysis of the collected data demonstrated that the guidelines on average water consumption used for design are greatly overestimated and should be updated. Furthermore, taking into account water consumption structure is necessary to correctly estimate unit sewage discharge in the rural households.

\section{REFERENCES}

1. Bergel T. 2005. Objętość ścieków odprowadzanych $\mathrm{z}$ gospodarstw wiejskich do kanalizacji w zależności od struktury zużycia wody wodociągowej. Rozprawa doktorska. AR w Krakowie, Wydział Inżynierii Środowiska.

2. Bergel T., Kaczor G. 2007. The volume of wastewater discharged from rural households to the sewer system in the light of tap water consumption structure. Polish Journal of Environmental Studies, Vol. 16, No. 2A, Part II, 109-112.

3. Bugajski P., Kaczor G. 2007. Struktura zużycia wody przez użytkowników wodociągu w gminie Drwina. Gaz, Woda i Technika Sanitarna, 2, 81-88. 
4. Ćwiertnia R. 2004. Prawidłowy wskaźnik jednostkowego zapotrzebowania wody - podstawa optymalnego zaprojektowania sieci wod.-kan. oraz obiektów wodociągowych i kanalizacyjnych. Forum Eksploatatora, 2, 14-17.

5. Heidrich Z. 1998. Przydomowe oczyszczalnie ścieków - poradnik. Centralny Ośrodek Informacji Budownictwa. Warszawa.

6. Jóźwiakowski K. 2012. Badania skuteczności oczyszczania ścieków w wybranych systemach gruntowo-roślinnych. Infrastruktura i Ekologia Terenów Wiejskich, 1, 62-64.

7. Pawełek J., Bergel T. 2003. Objętość ścieków bytowych a zużycie wody w gospodarstwach wiejskich. Inżynieria Rolnicza, 3(45), tom II, 81-89.

8. Pawełek, J. Kaczor, G. 2008. Charakterystyka zużycia wody w domu jednorodzinnym w dziesięcioletnim okresie badań. Gaz, Woda i Technika Sanitarna, 9, 22-24.
9. Pawęska K., Bawiec A., Włodek S., Smaga E. 2013. Wstępna analiza średniego zużycia wody w jednorodzinnych gospodarstwach domowych. Infrastruktura i ekologia terenów wiejskich, nr 1, 171-179.

10. Roman M., Kłoss-Trębaczkiewicz H., OsuchPajdzińska E. 1996. Zużycie wody i jego zmiany w dużych miastach polskich w latach 1984-1994. Międzynarodowa Konferencja Naukowo-Techniczna „Zaopatrzenie w wodę miast i wsi”. Poznań, 23-36.

11. Rozporządzenie Ministra Infrastruktury $\mathrm{z} d n$. 14.01.2002 r. w sprawie określenia przeciętnych norm zużycia wody (Dz. U. z dn. 31.01.2002 r.).

12. Ustawa $z$ dnia 7 czerwca 2001 r. o zbiorowym zaopatrzeniu w wodę i zbiorowym odprowadzaniu ścieków (Dz. U. nr 72, poz. 747).

13. Zarządzenie $\mathrm{nr} 1$ Ministra Rolnictwa $\mathrm{z} \mathrm{dn}$. 5.01.1966 r. w sprawie wytycznych do obliczeń zapotrzebowania na wodę w wiejskich jednostkach osadniczych (Dz. Bud. nr 3 z 1967 r., poz. 13). 